Tér és Társadalom 20. évf. 2006/1. 109-123. p.

Tér és Társadalom

XX. évf. 2006 1: 109-145

\title{
GYORS TÉNYKÉP
}

\section{VÁROSFELÚJÍTÁS PÉCS ÉS GYÖR TÖRTÉNELMI BELVÁROSÁBAN}

\author{
(Urban Renewal in the Historic City Centre of Pécs and Györ)
}

\author{
JANKÓ FERENC
}

Kulcsszavak:

városfeluijitás müemlékvédelem tơrténelmivárosrészek Pécs Györ

A tanulmány a két dunántúli nagyváros példáján mutatja be a történelmi városfelújítás fóbb múltbeli eseményeit, eredményeit, a történelmi belvárosok jelenbeli helyzetét, mind napjaink városfejlödési folyamataiban, mind a városok életében betöltött szerepuk szerint. A szerzó fö megállapitása, hogy a történelmi belvárosok megújítása egyfelöl a rendszerváltozást megelözỏ müemlékvédelmi munkák által kijelölt iránytól meghatározott, másfelöl a helyi önkormányzatok szerepvállalásától - elsōsorban felsőbb kormányzati szintek által determinált - lehetöségeitöl függ. A történelmi városrészek felújításának folyamata mindenképpen (kormányzati) üjragondolást igényel, illetve a szereplök együttmüködését, a források és eszközök koncentrálását, amely hozzájárulhat a müemlékek, illetve az épített örökség versenyképességéhez, mind a lakó-, mind a gazdasági funkciók tekintetében. Több konfliktus feloldásra vár tehát, igy az, hogy látszólag csak az új építésü épületek hoznak megújulást a történelmi belvárosokba, illetve a mủemlékek szociális bérház funkcioja. Mindezek ugyanis már rövidtávon is fenntarthatatlanná tehetik a „történelmi városrész"-t.

\section{Bevezetés}

A városföldrajzi, városszociológiai szakirodalomban a belső városrészekre a nyolcvanas évek végén irányult nagyobb figyelem, mindez talán a megkezdődő budapesti városrehabilitációs akcióknak volt köszönhetö. A történelmi városmagok, városrészek konzerválása, restaurálása stb., egyszóval felújítása elsősorban a müemlékvédelem sajátja volt, amely sajátos szervezeti-szakmai helyet foglalt, s foglal el ma is az építésügy és a kulturális örökségvédelem szakterülete között, jóllehet a fószerepet már az önkormányzatok játsszák!

A fentiek miatt elsősorban müemlékvédelmi, városépítési szaklapokban olvashatunk a történelmi városrészekról, jelen dolgozat más szakterületek, konkrétan a városföldrajz növekvő érdeklődésének egy ,,anyagiasulása” is kíván lenni. Az egyoldalú múemlékvédelmi, építészeti szempont hangsúlyossága mellett, a társadalmi és gazdasági jelenségek, következmények figyelembe vétele inkább csak járulékosan kapcsolódott a múemléki városfelújításhoz, fóképpen, amíg az az egyes védendó épületek szintjén munkálkodott. A múemlékvédelem lassan jutott el a területi védelem problematikájáig, aminek egyik mérföldköve volt a mủemléki jelentỏségủ területek $^{2}$ (MJT) kijelölése az 1960-as évek közepén. Mindez természetesen Pécs és 
Györ belvárosát is érintette. Dolgozatomban elsösorban erre a két területre, városrészre szeretnék koncentrálni - empirikus adatgyüjtéseim is ezt teszik lehetỏvé -, azonban nem kívánom szem elöl téveszteni a városok más történelmi jelzővel illethetö városnegyedeit $\mathrm{sem}^{3}$. Ugyanis ma már a mủemlékvédelem körei nemcsak idöben, hanem területileg is bővülnek, így többen felhívják a figyelmet a települési karakter vagy jellegvédelem fontosságára, aminek egyik viszonylag új eszköze a helyi értékvédelem jogi kategóriája (Lővei-Somorjay 2003; Magyar-Péter 2003; Máté 2001; Rácz 2001; Román 1973; 1983; 1984a).

\section{A városfelújítás múltja Pécsett és Györben}

Pécs településhálózati szerepköreiböl, a városhierarchiában elfoglalt helyzetéböl adódóan természetesen nem az egyébként országosan legnagyobb területú, müemlékileg védett terület, a belváros fejlesztésére, helyreállítására koncentrálta pénzeszközeit. Ezen a téren kisebb városképjavító beavatkozásokra futotta, sortatarozásra a Ferencesek utcájában, illetve a székesegyház és a dzsámi helyreállítása kezdődhetett meg. A város stratégiailag is fontos iparágak központja lett, s ennek is köszönhető, hogy több tízezres nagyságrendben kellett új lakásokat építenie. Az elöbbiekben elmondottak alapján sejthető az is, hogy Pécs új városközpont építésére is törekedett, amit a belvárostól délre fekvő helyen képzeltek el. A városfejlesztési prioritások ellenére már a hatvanas évek elején felmérések készülttek a belvárosban, majd az évtized végén a részletes rendezési terv is megszületett.

A hetvenes években nagy erőket koncentráltak a város római kori, kora középkori és török kori építészeti értékeinek vizsgálatára, feltárására, de szintén nagy erőket kellett mozgósítani a város alatti pincerendszer feltárásához és folyamatos állagmegóvási munkáihoz. 1981-re új RRT készült, amely már részletes helyreállítási stratégiát dolgozott ki a belvárosra, amelynek alapját az Egerben kifejlesztett tömbrekonstrukciós módszer jelentette. A helyreállítás akcióterületeit a városi tanács és az RRT közösen határozta meg, amelyek esetében komplex „tömbhasznosítási” tanulmányterv készült. Építészeti körökben nagy visszhangot váltott ki az Elefántos tömb helyreállítása, amely az első volt a sorban. A további munka azonban nagy akadályokba ütközött a váltólakás-hiányok és a magántulajdonú házak következtében.

Talán az MJT nagysága miatt, annak területén nem érvényesítettek egységes szemléletet a várostervezök. A legértékesebb épületállományú északnyugati szektort közösségi funkciókra szánták, így számos múzeum nyílt a felújított mủemlékekben, s a várfalak kiszabadítása és helyreállítása is leginkább ebben a városrészben indult meg. Az északkeleti negyed és főképpen a déli területek épületállományát már értéktelenebbnek ítélték, így azokat nagyobb fokú átépítésre tervezték. Ezekben a részekben már a rendszerváltozás elött több foghíjbeépítés történt a magántöke kezdeményezésére (Bálint 1968; Buzánszky-Bajta 1982; Kistelegdi 1982, 1986; Kriszt 1967, 1970; Piti 1987; Sedlmaymé Beck 1984; Varga 1984). 
Győr ékes példája a mủemlékvédelem és az építésügy konfliktusának, a történeti és nem történeti településrendezés egyidejü, egymás melletti tevékenységének (Winkler 1983). A győri MJT-t ugyanis minden bizonnyal elörelátó módon jelölték ki, s aztán sok helyütt egészen a határáig lebontották az avultnak, értéktelennek kikiáltott épületeket, így az MJT határából éles városképi választóvonal is vált, holott korábban szervesen kapcsolódtak a belvároshoz a délebbre található városrészek. De történtek indokolatlan bontások a védett területen belül is. Györött érvényesült az a sokáig ható szemlélet, amely a 19 . század végének építészeti emlékeit „tagadta”, értéktelennek, bontani valónak tartotta. Az ötvenes-hatvanas években a történelmi városmagot, mint egy túlzsúfolt, túlterhelt, városközponti szerepkörökre alkalmatlan városrészt kezelték, $s$ gondjait a déli peremén vezetett, széles föforgalmi út megvalósításával, az intézmények egy részének kitelepítésével, illetve Pécshez hasonlóan a délröl csatlakozó területen új városközpont építésével kívánták megoldani. A belváros ügye kimondottan háttérbe szorult: korszerüsítése csak elegendỏ váltólakás rendelkezésre állása esetén indulhatott meg.

A tervezők érzékelték, hogy a területen döntöen alacsony státuszú lakosság lakik, hasonló színvonalú lakásállományban, ezért célul tủzték ki az udvari szárnyak, hozzáépítések bontását, a földszinti egészségtelen, nedves lakások üzleti célokra való felhasználását. Az ötvenes években azonban csupán egyedi épület-helyreállítások történtek, a hatvanas évek sortatarozásának hatásai pedig hamar eltünedeztek. A hetvenes évektöl pozitív irányú változások kezdödtek. 1970-ben elkészült a mủemléki rekonstrukciós terv, megszületett a ,gyalogos-belváros" koncepció, s a lakóházak felújitására is egyre több pénz jutott. Idöközben az MJT déli határán megépült a forgalmi út keleti szakasza, ami mellett tizenegy szintes magasházak épültek, a nyugati szakasz viszont sohasem készült el. Majd egykori földszintes házak helyén és a megmaradtak szomszédságában kiemelkedett a földböl a monumentális színház épülete is (Acél 1985; Aczél-Lombár 1982; Fátay 1962, 1967; Kriszt 1967, 1970, 1976, 1985; Peschka 1983; Román 1984b; Sedlmayrné Beck 1984; Varga 1982; Winkler 2004).

A nyolcvanas években már tervszerủ stratégia alapján folyt a belváros nyugati részének revitalizációja, rehabilitációja. Győrött is alkalmazták a tömbrehabilitációt: a városfelújítást tömbökre összpontosították, számos tömbbelsót felnyitottak, az udvari szárnyak némelyikét lebontották. A lakásokat is a lehető legkorszerübb módon alakították ki, az esetleges megszünéseket tetỏtér beépítésekkel ellensúlyozták. Az évtized végére ennek a munkának elismeréséül Sopronhoz hasonlóan Győr is múemlékvédelmi Európa díjat kapott (1989). A rendszerváltozás után a felújítások megtorpantak, a színház körüli földszintes negyedek is megmaradtak, bontásukra már nem futotta. Itt már a magánerös megújulás hozott - ám korántsem oly drasztikus - változást (Kubinszky 1987; Varga 1986, 1990; Winkler 1987, 1996, 2004). 
Jankó Ferenc : Városfelújitás Pécs és Györ történelmi belvárosában

Tér és Társadalom 20. évf. 2006/1. 109-123. p.

\section{1. ÁBRA}

Pécs történelmi belváros épületeinek épitési ideje, 2005

(BuildingPperiod of Houses in the Historic City Centre of Pécs, 2005)

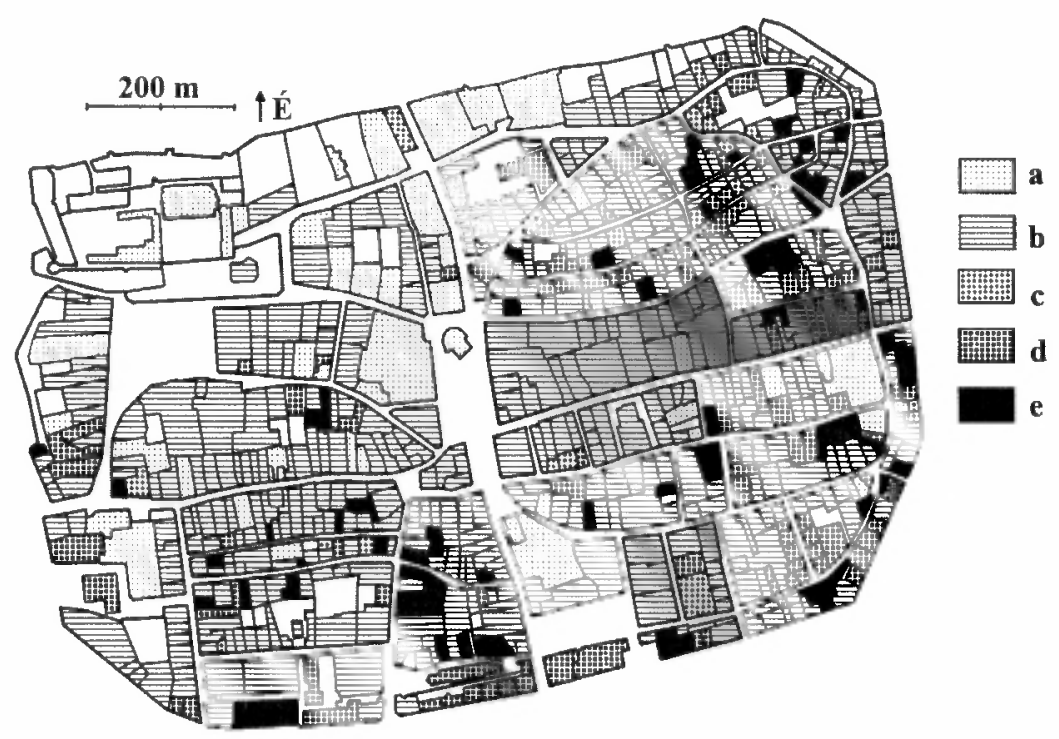

Jelmagyarázat: a: -1800 b: 1800-1930 c: 1930-1945 d: 1945-1990 e: 1990-

Forrás: Saját adatok.

\section{Városfelújitás a jelenben}

Pécs és Györ - hasonlóan sok más magyar és külföldi városhoz - jellegzetes topográfiai alap-szerkezettel bír: viszonylag kompakt várostest, amelynek északnyugati sarkában, felében volt a belsö védmü, a pécsi Püspökvár, illetve a györi vár a Káptalan dombon. Ez esetünkben abból a szempontból lényeges, hogy jelentösen determinálta - mint ahogy fentebb részleteztem - a felújítások területi koncentrálását, továbbá a funkcionális hasznosítás alakulását is. Az 1 . és 2. ábra alapján látható, hogy az épületállomány változásának területi jellege is hasonló mintázatot ölt mindkét városban, egy lényeges különbséggel. Az 1945 után épített házak Györben az MJT-t, Pécsett viszont nagyjából az északnyugati szektort határolják övszerúen.

Vagyis Pécsen a már a rendszerváltozás elött elhatározott tervezői szándék szerint folyik tovább a most már spontán(abb) városmegújitás, elsősorban a magántőke által irányítottan, ugyanis a történelmi belvárosban alig maradt néhány lakóház, illetve lakás önkormányzati tulajdonban. Ez számos kérdést felvet, illetve konfliktust gerjeszt. Pécs városfejlesztési, illetve -rendezési dokumentumai. de legutóbb az Európai Kulturális Fövárosa 2010 (EKF) pályázatra készített anyag is felhívja a figyelmet a magánerős városmegújítás visszásságaira, indokolatlan bontásaira, a városképet erodáló, atomizáló tevékenységére. Az EKF pályázatban ezért is hang- 
súlyos a kulturális városfejlesztés koncepciójának, illetve egy új mủemlékgondozási modellnek a kidolgozása, amelyben egyrészt a helyi védelem eszközének az erősítésére, másfelöl a müemlékvédelem és az építész szakma kívánatos jobb együttmüködésére hívják fel a figyelmet.

\section{2. ÁBRA}

Györ történelmi belváros épületeinek építési ideje, 2004

(Building Period of Houses in the Historic City Centre of Györ, 2004)

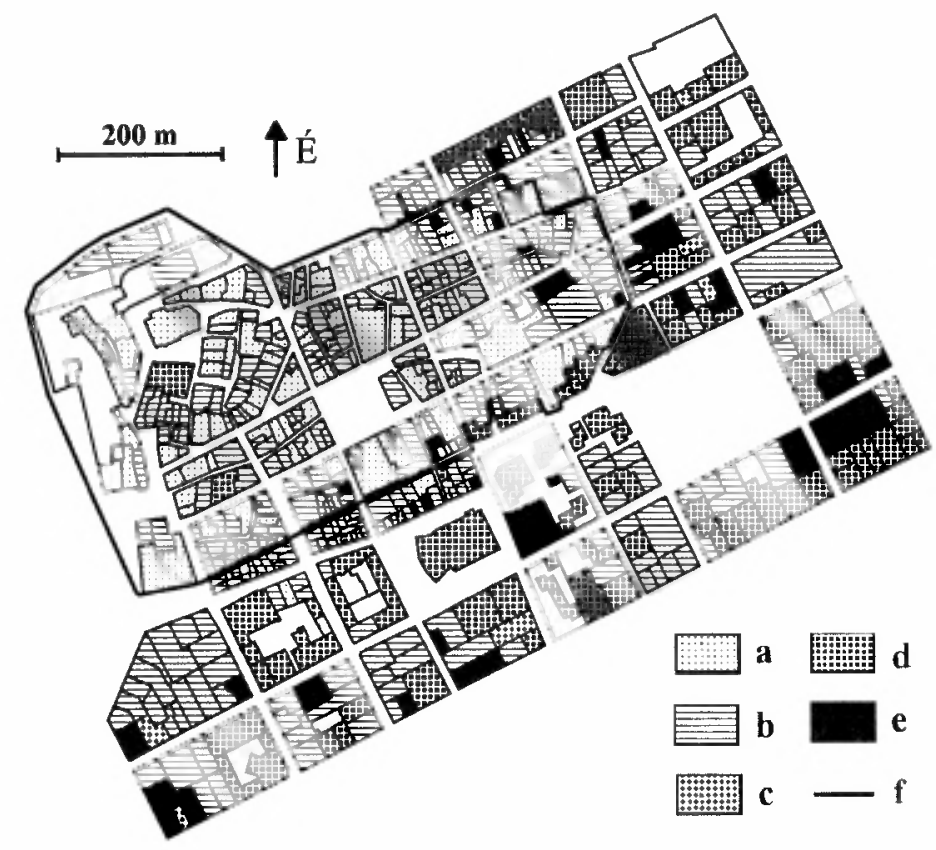

Jelmagyarázat: a: -1800 b: 1800-1930 c: 1930-1945 d: 1945-1990 e: 1990-f: MJT határa

Forrás: Saját adatok.

\section{TÁBLÁZAT}

Pécs belvárosi lakóházainak állapota, védettség és tulajdonos szerint, 2005 (\%)

(Condition of Dwelling Houses after Protection and Owner in the City Centre of Pécs, 2005, \%)

\begin{tabular}{lcccc}
\hline & $\begin{array}{c}\text { Müemlék } \\
(67)\end{array}$ & $\begin{array}{c}\text { Nem-müemlék } \\
(451)\end{array}$ & $\begin{array}{c}\text { Önkormányzati } \\
(25)\end{array}$ & $\begin{array}{c}\text { Magán, } \\
\text { vegyes (493) }\end{array}$ \\
\hline Újszerú & 17,9 & 20,4 & 16,0 & 20,3 \\
Jó & 38,8 & 47,9 & 32,0 & 47,5 \\
Enyhén sérült & 34,3 & 26,2 & 32,0 & 27,0 \\
Közepesen sérült & 9,0 & 4,7 & 20,0 & 4,5 \\
Erösen sérült & 0,0 & 0,9 & 0,0 & 0,8 \\
Romos & 0,0 & 0,0 & 0,0 & 0,0 \\
\hline
\end{tabular}

Forrás: Saját adatok. 
Győrben szintén elmondható, hogy a magántőke folytatta azt, amit a közösségi tervezés korábban elöirányzott, illetve Györben hangsúlyosan el is kezdett, gondoljunk csak a MJT déli határára, ahol előbb panelházak, majd posztmodern társasházak épültek, már a rendszerváltozás környékén. Lényeges különbség még Péccsel szemben, hogy Győrben az önkormányzat nem vonult ki a történelmi belváros megújításából, abban azáltal is tevékeny szerepet vállal, hogy a mintegy 146 müemlék lakóházból 93 van tisztán városi kézben ${ }^{4}$. Mindez az épületállomány állagának megoszlásában is tükröződik (1. és 2. táblázat).

\section{TÁBLÁZAT}

Györ belvárosi lakóházainak állapota, védettség és tulajdonos szerint, 2004 (\%) (Condition of Dwelling Houses after Protection and Owner in the City Centre of Györ, $2004, \%$ )

\begin{tabular}{lcccc}
\hline & $\begin{array}{c}\text { Müemlék } \\
(146)\end{array}$ & $\begin{array}{c}\text { Nem-müemlék } \\
(313)\end{array}$ & $\begin{array}{c}\text { Önkormányzati } \\
(111)\end{array}$ & $\begin{array}{c}\text { Magán, } \\
\text { vegyes (348) }\end{array}$ \\
\hline Újszerü & 18,5 & 18,8 & 21,6 & 17,8 \\
Jó & 39,0 & 41,2 & 32,4 & 43,1 \\
Enyhén sérült & 30,8 & 32,6 & 31,5 & 32,2 \\
Közepesen sérült & 10,3 & 5,8 & 10,8 & 6,0 \\
Erősen sérült & 1,4 & 1,0 & 1,8 & 0,9 \\
Romos & 0,0 & 0,6 & 1,8 & 0,0 \\
\hline
\end{tabular}

Forrás: Saját adatok.

Pécs esetében megállapítható, hogy a mủemlék és az önkormányzati tulajdonú lakóházak állaga összességében kedvezötlenebb képet mutat. Györben mindkét felosztást tekintve kedvezőbb a helyzet, több a felújított mủemlék/önkormányzati lakóház, bár összességében talán ugyanúgy a nem-védett, illetve a magán és vegyes tulajdonú lakóházak állapota jobb. Györben tehát nagyobb energiákat ölnek a lakóházak karbantartásáras.

Győr esetében a tulajdoni viszonyok és a lakóházak állapota alapján - illetve a 2. ábra ismeretében - különbözö típusú lakóterületeket lehet elkülöníteni (3.ábra). A térképen 1-es számmal jelölt területen szervezett mủemléki felújítások folytak már 1990-et megelözően, itt az önkormányzat aktívan viseli ma is a városmegújítás terheit. A 2-es jelü részen szintén sok az önkormányzati lakóház, ezek állapota azonban többnyire felújításra szorul, itt a magántőke játszik húzó szerepet. A 3-as terület potenciálisan hanyatló terület panel tömbházakkal, míg a 4-es részen jelenleg is magánerős városrehabilitáció zajlik, a részben az önkormányzat által átadott területen, mintegy befejezve azt, amit korábban a város elkezdett. 


\section{3. ÁBRA}

Györ történelmi belváros lakóházai tulajdonos és állapot szerint, 2004

(Dwelling Houses after Condition and Owner in the Historic City Centre of Györ, 2004)

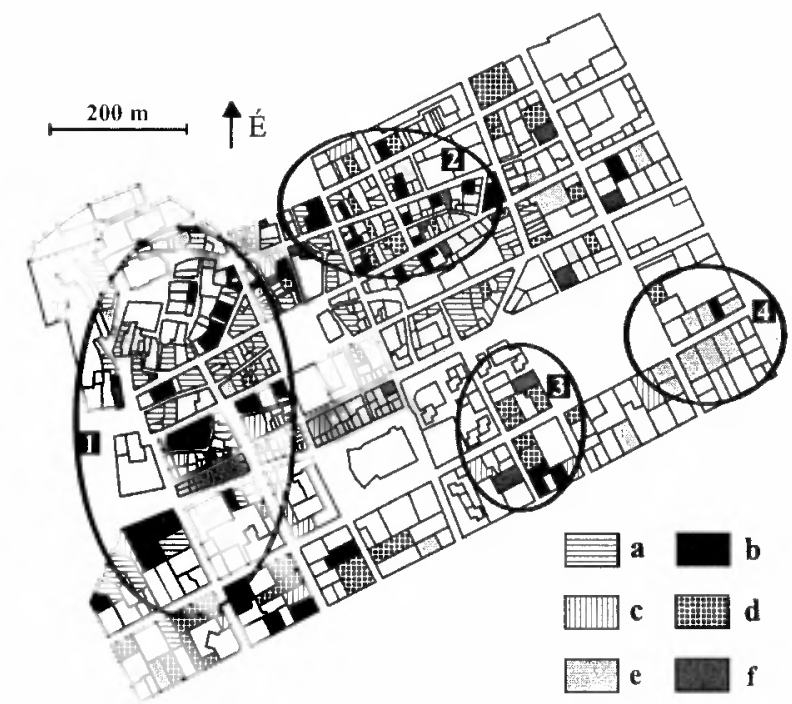

Jelmagyarázat: a: Önkormányzati, újszerủ vagy jó; b: Önkormányzati, sérült; c: Vegyes, újszerü vagy jó; d: Vegyes, sérült; e: Magán újszerú; f: Magán közepesen sérült vagy roszszabb; $1-4$. Jellegzetes városfelújítási területek, magyarázatot lásd a szövegben.

Forrás: Saját adatok.

\section{4. ÁBRA}

Vezetö, értelmiségi foglalkozásúak aránya, Pécs történelmi városrész, 2001 (\%) (Ratio of Managerial and Intellectual Employees, Historic City Centre of Pécs, 2001, \%)

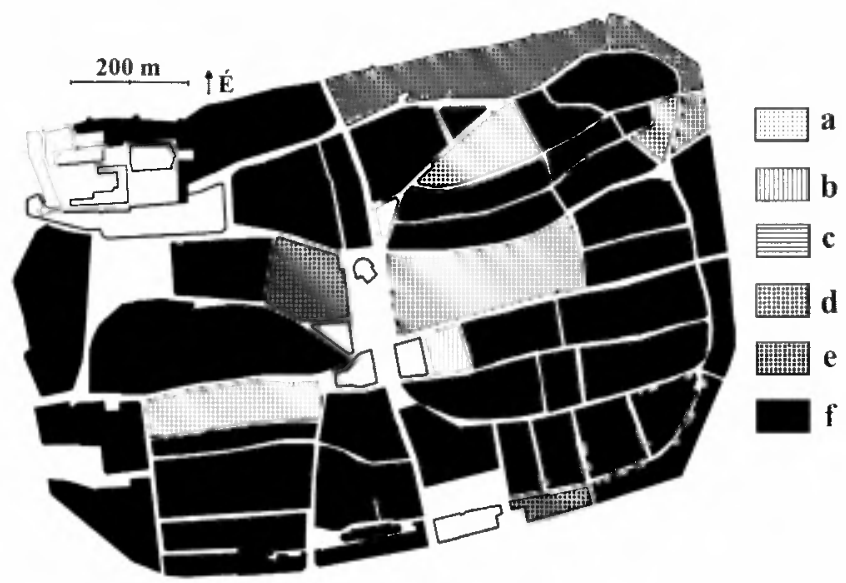

Jelmagyarázat: a: 0-8; b: 8-16; c: 16-24; d: 24-32; e: 32-40; f: 40 felett; Pécs átlaga: 27.7

Forrás: KSH alapján saját számítás. 


\section{Társadalmi folyamatok}

A történelmi belvárosokban zajló társadalmi folyamatok felderítése az 1990-es és a 2001-es népszámlálási adatok segítségével történhet. Ezek az adatok pedig azt mutatják, hogy presztízs Pécs és Györ belvárosában lakni, a városi átlaghoz képest ugyanis magas a felsöfokú végzettségủek, illetve a vezetö, értelmiségi foglalkozású lakosság aránya (4. ábra). 1990 óta a pécsi belvárosban számos háztömbben és a györi városmag szinte teljes területén csökkent az idöskorúak aránya, ám ennek ellenére jobbára még mindig átlag felett részesednek a lakónépességböl. A gyermekkorúak aránya viszont szinte mindenhol nagyon alacsony, s a mutatóban bekövetkezett javulás is nagyon kevés tömbben regisztrálható (5.ábra) ${ }^{6}$.

\section{5. ÁBRA}

Idöskorúak arányának változása, Györ történelmi városrész, 1990-2001 (\%) (Changing of Aged People's Ratio, Historic City Centre of Györ, 1990-2001, \%)

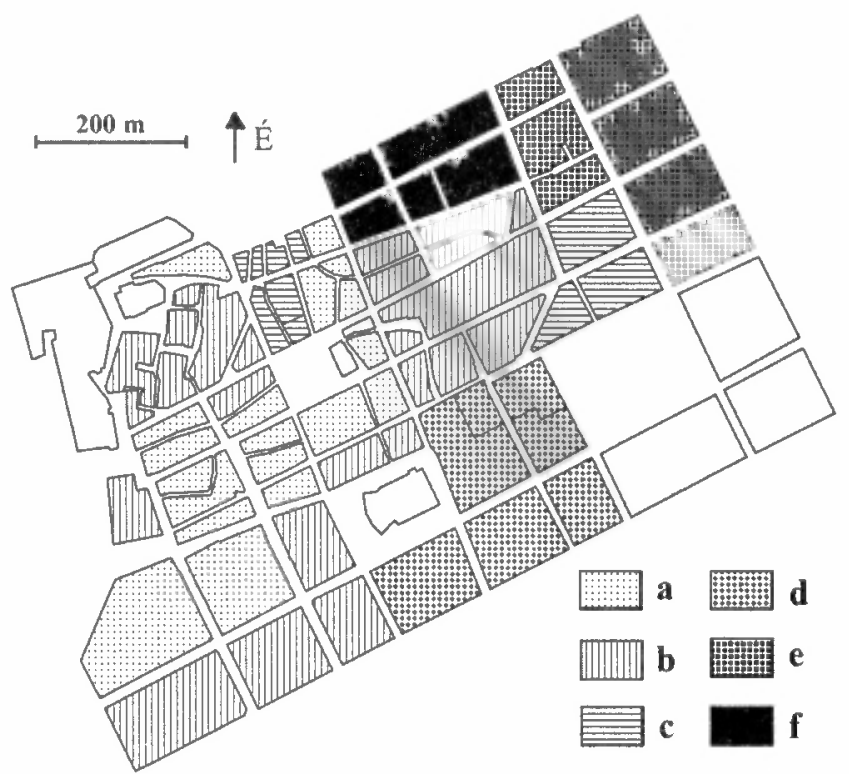

Jelmagyarázat: a: -3 ałatt; b: -3-0; c: 0-3; d: 3-6; e: 6-9; f: 9 felett; Győr átlaga: 2,4

Forrás: KSH alapján saját számítás.

A lakásállomány néhány mutatóját szemügyre véve megállapítható, hogy még mindig van feladat a müemlékvédelemben. Számos ház korszerüsítésre várna, a lakások komfortfokozatát, alapterületét még mindig javítani, növelni kellene, s a városmagok területe zsúfoltabbnak is mutatkozik. Az egyszobás lakások magas aránya például gátja lehet a gyermekes családok nagyobb arányú beköltözésének, illetve helyben maradásának. Ugyan 1990 óta jelentős javulások következtek be, ám 
ebben szerepet kaphatott a lakások áthasznosítása vagy tényleges lakatlanná válása is. A győri MJT némely mutató alapján különösen jól kiválik környezetéböl, jelezve a szüken vett történelmi városrész rosszabb állapotú lakásállományát. Mindez arra is visszautal, hogy az épületek állapotára vonatkozó korábbi megállapítások némi fenntartásokkal kezelendők, mivel az állagot a homlokzatok alapján állapítottuk meg. Ez a szakmailag sokszor kárhoztatott sortatarozások jelenlétére is utalhat (6. ábra).

\section{6. ÁBRA}

Félkomfortos, komfort nélküli, szükség és egyéb lakott lakások aránya, Györ történelmi városrész, 2001 (\%)

(Joint Ratio of Populated Dwellings with Semi-comfort, without Comfort and Emergency Dwellings, Historic City Centre of Györ, 2001, \%)

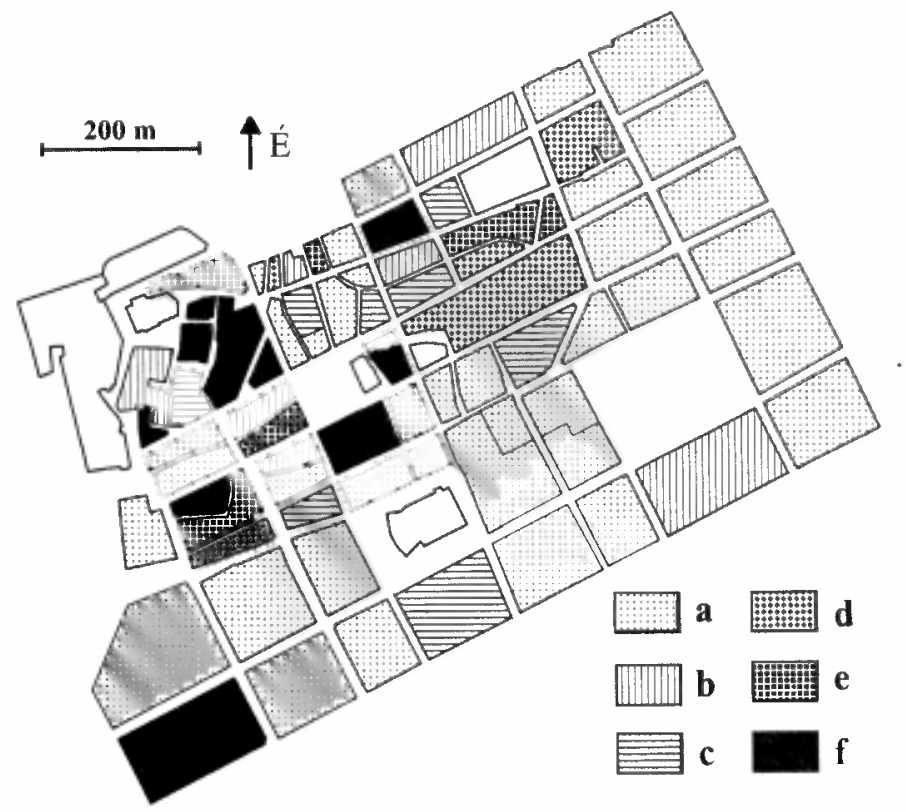

Jelmagyarázat: a: 0-4; b: 4-8; c: 8-12; d: 12-16; e: 16-25; f: 25 felett; Győr átlaga: 6,1

Forrás: KSH alapján saját számítás.

Vagyis némileg sarkítva azt mondhatjuk, hogy Pécs és Györ történelmi belvárosában az idöskorúak mellett jelentős számban élnek magas társadalmi státuszú lakosok, akik valószínủleg yuppie-nek vagy dinky-nek bizonyulnak ${ }^{7}$, ugyanis nagyon kevés a gyerek, hiszen a nagyobb létszámú családok jelenlétének a kisebb lakások sem kedveznek. Ugyanakkor a lakásminöség mutatók, s Győrben az önkormányzati bérlakások jelenléte figyelmeztetnek, hogy még mindig jelen van egy alacsony státuszú - részben idős - lakosság is. A lakásnagyság - mint a magasabb státuszú, gyermekes családok beköltözésének befolyásolója - tekintetében pedig arra kell felhívni a figyelmet, hogy amennyiben a müemlékeket nem korszerüsítik úgy, hogy 
lakásösszevonásokkal, alaprajz korszerüsítésekkel nagyobb lakásokat alakítanak ki, csak az új építés hozhat ilyen irányú megújulást e városrészek életébe.

\section{7. ÁBRA}

Pécs történelmi városrész épületeinek funkcionális típusai, 2005

(Functional Types of Houses in Historic City Centre of Pécs, 2005)

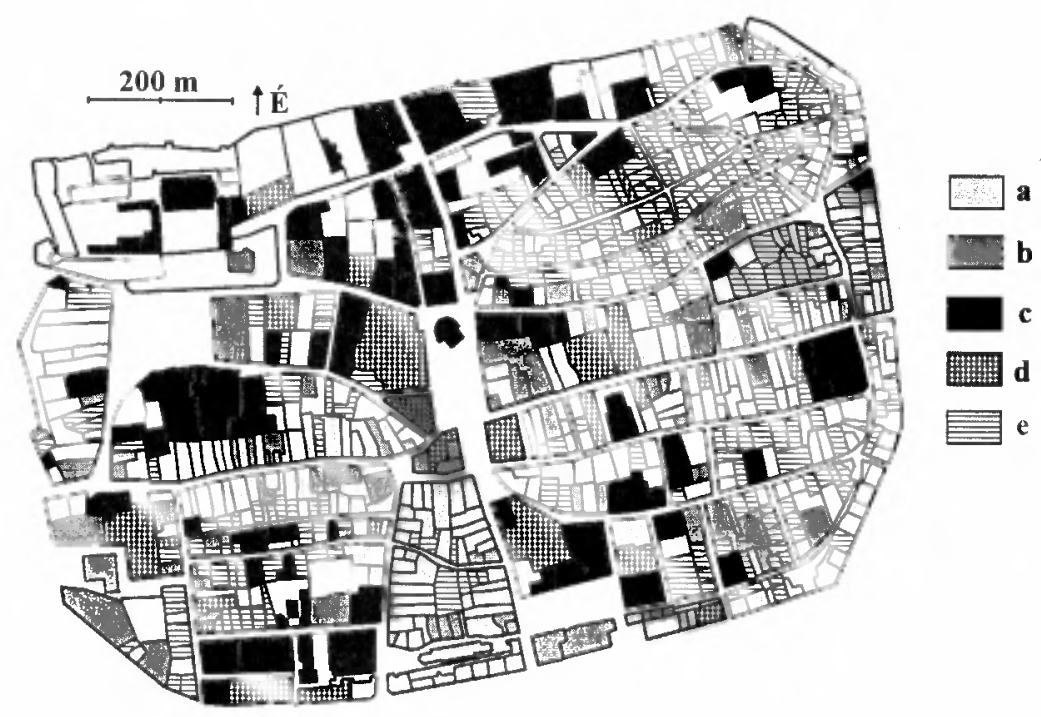

Jelmagyarázat: a: Lakóház az utcafronton üzletekkel; b, c, d: Nem lakóház: b: Gazdasági funkció; c: Közintézmény, egyház; d: Gazdasági funkció és közintézmény; e: Lakóház, nem-lakó funkció nélkuil.

Forrás: Saját adatok.

\section{A belvárosok funkcionális szerepe}

A történelmi belvárosok hagyományosan a városi élet középpontjai, funkcionális hasznosításuk is tükrözi városközponti szerepüket. Győr és Pécs történelmi városmagja megtartotta ezt a rangot, jóllehet föképpen az államszocializmus időszakában oldottak ezen. Győrben elsősorban közintézményeket költöztettek ki az „új városközpontba", ám a kereskedelmi, szolgáltató központ nagyjából a helyén maradt. Pécsen is épült új városközpont, bár talán kevésbé markáns, mint Győrött, de a rendszerváltozás utáni folyamatok ismeretében azt lehet mondani, hogy a kereskedelmi funkciók terén is gyengült a pécsi városmag, hiszen nagy bevásárlóközpont nyílt közvetlenül annak déli szélén. A városok peremén épülő kereskedelmi zónák hatását még kevéssé lehet érzékelni, bezárt üzletek tömegével egyelőre nem találkozni, a boltok profil-, illetve színvonalváltása - pl. kínai üzletek megjelenése lehet az, ami jelzi a változásokat (7. és 8. ábra). 


\section{8. ÁBRA}

Györ történelmi városrész épületeinek funkcionális típusai, 2004

(Functional Types of Houses in Historic City Centre of Györ, 2004)

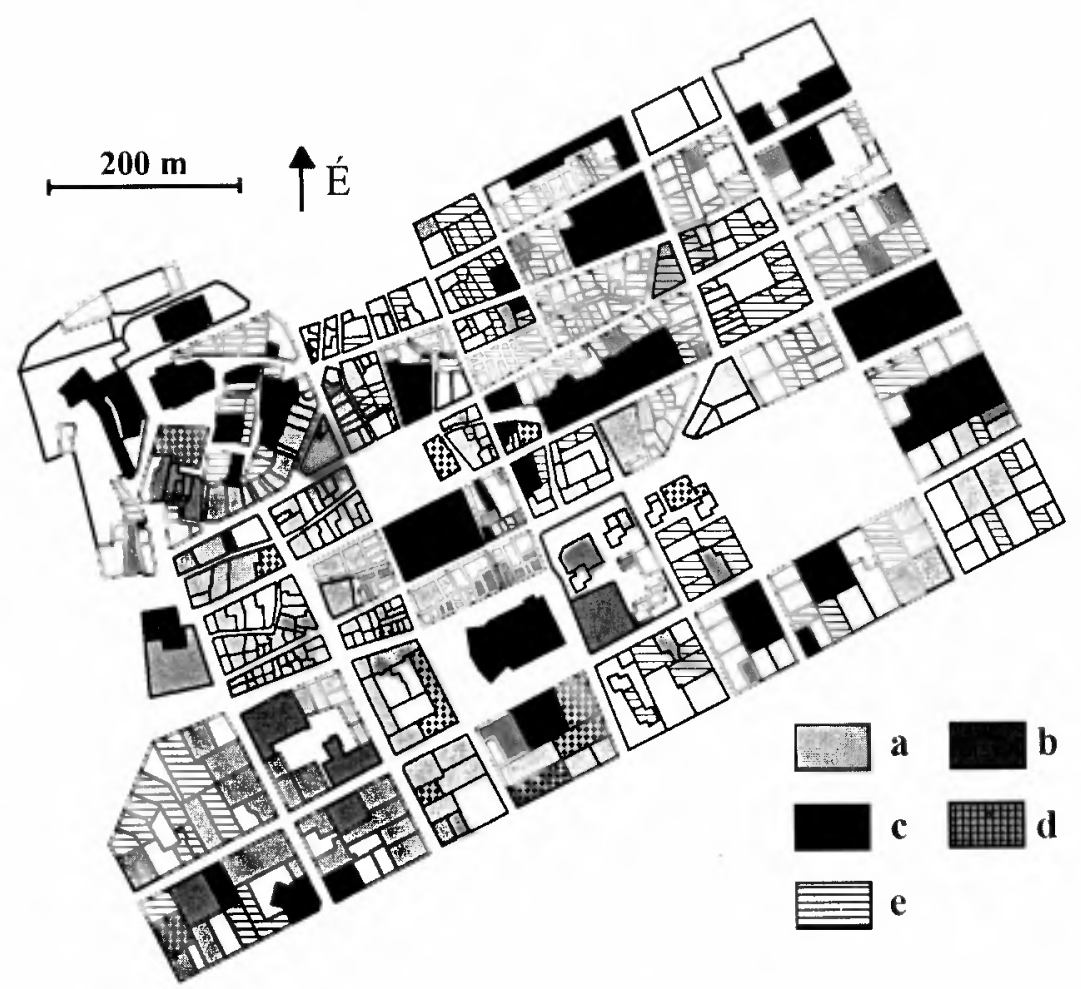

Jelmagyarázat: a: Lakóház az utcafronton üzletekkel; b, c, d: Nem lakóház: b: Gazdasági funkció; c: Közintézmény, egyház; d: Gazdasági funkció és közintézmény; e: Lakóház, nem-lakó funkció nélkül.

Forrás: Saját adatok.

Érdemes megnézni a két városmag adatait újfent, néhány háztípus csoportosításában, most a funkcionális hasznosítás tekintetében - vegyük egyszer a müemlékeket, másodszor az 1945 elött épült házakat épített örökségnek. Pécset tekintve kidomborodik a belvárosban a mủemlékek közintézményi szerepe, ami nagyrészt a „múzeumi negyed"-nek köszönhetö. Az üzleteket, vendéglátást nézve is a múemlékek előnye mutatkozik a nem-védett épületekkel szemben, az irodai hasznosításban viszont adataim szerint - rosszabb lehetőségeket kínálnak a védett házak. Ha az épített örökség másik definíciója szerint vesszük számba az adatokat, akkor viszont egy egészen más kép rajzolódik ki. Ezek szerint az újabb, s különösen a manapság épülő házak bírnak nagy funkciósủrüséggel (3. táblázat). 


\section{TÁBLÁZAT}

Pécs belváros épületeinek funkciósürüsége védettség és kor szerint, 100 házra jutó funkció

(Function Density of Houses after Protection and Age in the City Centre of Pécs,

Function per 100 houses)

\begin{tabular}{lccccc}
\hline & $\begin{array}{c}\text { Müemlék } \\
(134)\end{array}$ & $\begin{array}{c}\text { Nem- } \\
\text { müemlék } \\
(608)\end{array}$ & $\begin{array}{c}1945 \\
\text { elött } \\
\text { épült } \\
(576)\end{array}$ & $\begin{array}{c}1945-90 \\
\text { közö́tt } \\
\text { éplt(104) }\end{array}$ & $\begin{array}{c}1990 \\
\text { után } \\
\text { épillt } \\
(62)\end{array}$ \\
\hline Közintézmény, egyház & 50,0 & 13,2 & 22,9 & 8,7 & 9,7 \\
Iroda, magánrendeló & 39,6 & 43,6 & 38,5 & 37,5 & 91,9 \\
Kereskedelem, & 81,3 & 64,0 & 62,8 & 67,3 & 106,5 \\
szolgáltatás & 4,5 & 4,3 & 1,6 & 6,7 & 25,8 \\
ebböl: Bank, biztosító & 20,1 & 11,7 & 13,7 & 8,7 & 16,1 \\
Vendéglátás, szállásadás & 12,7 & 46,2 & 39,2 & 51,9 & 29,0 \\
Csak lakófunkció & & & & \\
\hline
\end{tabular}

Forrás: Saját adatok.

\section{TÁBLÁZAT}

Györ belváros épületeinek funkciósürüsége védettség és kor szerint, 100 házra jutó funkció

(Function Density of Houses after Protection and Age in the City Centre of Györ, Function per 100 houses)

\begin{tabular}{lrrrrr}
\hline & $\begin{array}{c}\text { Müemlék } \\
(191)\end{array}$ & $\begin{array}{c}\text { Nem- } \\
\text { müemlék } \\
(423)\end{array}$ & $\begin{array}{r}1945 \\
\text { elött } \\
\text { épült } \\
(455)\end{array}$ & $\begin{array}{c}1945-90 \\
\text { között } \\
\text { épult (117) }\end{array}$ & $\begin{array}{r}1990 \\
\text { után } \\
\text { épült } \\
\text { (44) }\end{array}$ \\
\hline Közintézmény, egyház & 22,5 & 13,2 & 15,4 & 20,5 & 11,4 \\
Iroda, magánrendeló & 18,8 & 47,0 & 23,7 & 59,8 & 129,5 \\
Kereskedelem, & 107,9 & 103,1 & 92,1 & 145,3 & 120,5 \\
szolgáltatás & 1,6 & 9,7 & 2,4 & 11,1 & 45,5 \\
ebböl: Bank, biztosító & 16,8 & 13,9 & 15,2 & 12,0 & 18,2 \\
Vendéglátás, szállásadás & 21,5 & 28,8 & 28,1 & 26,5 & 9,1 \\
Csak lakófunkció & 21,5 & & & & \\
\hline
\end{tabular}

Forrás: Saját adatok.

Győrben némileg eltérő a helyzet, a müemlékek közintézményi szerepe nem domborodik ki annyira, üzleti súlyuk is kevésbé markáns - ami talán annak köszönhetö, hogy Pécshez képest Győrben sokkal szórtabban helyezkednek el. A másik tipizálás szerinti adatok már egybevágnak a fentebb elmondottakkal, $\mathrm{s}$ ismét csak alá kell húzni az irodák és a bankok erős cityképzỏ hatását, amelyet úgy tünik, jobban szeretnek új építésủ épületekben kifejteni (4. táblázat). De a két várost a volumenek szerint is érdemes összevetni. A györi belváros funkcionális többlete vagy a bevásárló turizmus, vagy pedig az egész várost tekintve koncentráltabb üzlethálózat számlájára írható. 


\section{Befejezés}

A dolgozatban tárgyalt két hazai nagyváros számos vonatkozásban hasonlónak mutatkozik, így a városfelújítás múltjában, a hasonló társadalmi dinamikában, a regisztrálható dzsentrifikációban, a magánerős megújulás jelenlétében, a funkcionális szerkezetben. De vannak különbségek is. A két város esete rávilágít például a mủemléki jelentőségü területek eltérỏ szerepére, míg a győri sokkal egységesebb, a határán és azon kívül élesednek a városképi kontrasztok, addig a pécsi határain belül tapasztalható a fragmentálódás, azt a veszélyt rejtve magában, hogy az északkeleti negyed területére redukálódik az építészetileg hiteles történelmi városmag. Az önkormányzati szerepvállalás is eltérỏ a két városban, a győri kezében van több lehetőség és feladat is egyben, a történelmi városfelújítás húzójaként, elökészítőjeként, beindítójaként, de hátráltatójaként egyaránt szerepelhet a különböző területeken. Pécs inkább csak a közvetett eszközöket alkalmazhatja, mint például a közterület-fejlesztést, aminek jó példái az EKF pályázatban foglalt elképzelések.

Mindent összevetve az önkormányzatok súlya eltörpül a magántőke szerepe mellett; jelenleg a társadalmi és a gazdasági megújulás fö hordozóinak az új építésủ házak mutatkoznak. De kérdés, hogy milyen városképi áron kell ez a megújulás? S mindez a múemléki rehabilitációval kapcsolatban is felvet kérdéseket; úgy tünik, hogy az csak különbözỏ, szakmai és pénzügyi eszközök koncentrálása esetén válhat sikeressé, illetve hozhat további vitalitást a történelmi városrészek életébe. Ehhez pedig nemcsak városi szintủ elhatározás, hanem kormányzati akarat is kell, megfelelő finanszírozási, pályázati lehetőségek vagy akár erős szakmai háttér, illetve segítség formájában. El kell érni, hogy a múemlékek, illetve az épített örökség is versenyképes legyen a város felújításban, azaz mind a lakó-, mind a gazdasági funkciók tekintetében.

A történelmi városmagok jövőbeli funkcionális szerepével kapcsolatban is felmerülnek kérdések. Nyugati példák alapján ismert e városrészek funkcionális kiürülése, amelynek során csak turistákat kiszolgáló üzlettípusok maradnak, míg a helyi lakosság ellátatlanná válik. Erre reális veszély van Magyarországon is, ezért már most tenni kell ellene. A belvárosi üzleteknek számos elönye van a városszéliekkel szemben központi helyzet, hagyomány, hangulat - az ezekre való ráerösítéssel, illetve további vevőcsalogató eszközökkel fenntarthatóak lehetnek a belvárosi üzletnegyedek.

Ám a történelmi városfelújítás nem csak a belvárosokban talál feladatot, a történelmi külvárosok ügye továbbra is háttérbe van szorítva. Az EKF pályázat nagy pozitív hozadéka ebből a szempontból, hogy Pécs és Györ is felfedezte történelmi külvárosait - a Tettyét ${ }^{8}$, illetve Újvárost -, amelyek felhozatala nem csak hangulatos lakóterületek formájában válhat a városok hasznára, hanem tágíthatják azok imázsát is, így hozzájárulhatnak a helyi lakosság kötődésének erősítéséhez, illetve a turisztikai piacon való sikeresebb megjelenéshez. 


\section{Jegyzetek}

${ }^{1}$ A mủemlékvédelem az államszocializmus ideje alatt sajátos szervezeti keretek között múködött: Európa szerte egyedulállóan az építésügyi minisztérium irányítása ală tartozott, s a kutató, tervezö, és kivitelezó feladatok mellett idóvel építési hatósági, majd gondnoki, ingatlankezelő feladatokat is kapott. Az utódként 1992-ben létrejött Országos Mủemlékvédelmi Hivatal, majd a 2001-ben megalakult Kulturális Örökségvédelmi Hivatal meggyengült finanszírozási háttérrel továbbra is ellát államigazgatási és szakmai feladatokat, már újfent a kultuszminisztérium elsödleges felügyelete alatt (Dercsényi 1960; Erö 2005; Magyar-Péter 2003; Mezös 2002).

2 Sok kritika érte a múemléki jelentőségü területek kijelölését, de Pécsett hibátlanul, illetve Györben kỏzelítően fedik az egykori történelmi - várfalakkal övezett - város terủletét.

${ }^{3}$ Pécs esetében pontosan az MJT-t, a részben ma is városfallal övezett belvárost mértük fel, Györ esetében viszont annál nagyobb területen vállalkoztunk empirikus adatgyüjtésre. Ez Pécsnél 775, Györnél pedig mintegy 627 felmért egységet - telket, házat - jelentett. A lakóházak tulajdoni viszonyaira vonatkozóan a Pécsi Városuzemeltetési és Vagyonkezelő Rt. és a Györi Önkormányzati Ingatlankezelỏ és Szolgáltató Rt. bocsátotta rendelkezésemre az adatokat.

${ }^{5}$ A nem lakófunkciójú épủletek természetesen minden tulajdonosi kategóriában jobb állapotban vannak.

${ }^{6}$ A dinamikus térképen már nem háztömb szintủek az adatok, ugyanis a népszámlálások 1990-es szămlálókörzet és a 2001-es háztömb szintủ adatait közös nevezóre kellett hozni az összehasonlítás érdekében.

${ }^{7}$ Yuppie = young urban professional; Dinky = Double income no kids yet

${ }^{8}$ A pécsi pályázat kijelenti, hogy a Tettye hazánk egyetlen történelmi korú külvárosa. Jól tudjuk, ez nem így van, maga Győr, valamint Sopron, Köszeg, Veszprém, Eger stb. is tiltakozhatna a „történelmi külváros cím" kisajátítása ellen.

\section{Irodalom}

Aczél G. (1985) A városrehabilitációs tervek végrehajtásának kérdései Győr belváros példáján. - Telepïlésfejlesztés. 1. 107-112. o.

Aczél G.-Lombár I. (1982) Gyỏr-Belváros gyalogosközpont lehetőségei és problémái. - Településfejlesztés. 1. 89-91. o.

Bálint J. (1968) Az épuiló Pécs. - Városépítés. 1. 5-8. 0.

Buzánszky B.-Bajta D. (1982) Jogi problémák Pécs belváros rehabilitációjának magvalósítása során. Városépités. 5. 8-10. o.

Dercsényi D. (1960) Tíz év magyar mủemlékvédelme. - Magyar müemlékvédelem 1949-59. Országos Müemléki Felügyelőség Kiadványai I. Akadémiai Kiadó, Budapest. 9-28. o.

Erö Z. (2005) Mủemlékvédelem és városfejlödés. - Egedy T. (szerk.) Városrehabilitácio és társadalom. MTA FKI, Budapest. 269-287. o.

Fátay T. (1962) Győr tơrténelmi városmagja. - Mũemlékvédelem. 2. 93-97. o.

Fátay T. (1967) Gyôr városrendezésének gyakorlata. - Városépités. 3. 2-6. o.

Kistelegdi I. (1982) Pécs történeti városközpontjának rehabilitációja. - Városépítés. 4. 18-21. o.

Kistelegdi I. (1986) Pécs történeti belváros rehabilitációjáról. - Magyar Építőipar. 9-10. 542-554. 0.

Kriszt Gy. (1967) Győr történeti városmagjának rekonstrukciós kérdései. - Városépités. 3. 7-11. o.

Kriszt Gy. (1970) Történeti városaink rekonstrukciós problémái Pécsett és Győrben. - Magyar Mũem. lékvédelem. 1967-1968. Országos Múemléki Felủgyelőség Kiadványai V. Akadémiai Kiadó, Budapest. 251-267. 0 .

Kriszt Gy. (1976) Győr történeti városmagjănak mủemléki és városrendezési problémái. - Területrendezés. 1. 54-60. o.

Kriszt Gy. (1985) Györ történeti városmagja rekonstrukciója. - Müemlékvédelem. 2. 89-101. o.

Kubinszky M. (1987) A Györ belvárosi tömbrekonstrukciókról és építkezésekröl. - Városépítés. 3. $29-31$. o.

Lövei P.-Somorjay S. (2003) Főmủ és átlag - a múemlékké nyilvántartás elveiröl. - Müemlékvédelem. 2. 77-80. 0 .

Magyar M.-Péter A. (2003) Az építészeti örökség védelme. - KJK-KERSZÖV Kiadó, Budapest. 240 o.

Máté Zs. (2001) A városszerkezet mint mủemlék. - Falu Város Régio. 6. 6-9. o.

Mezős T. (2002) Elmélet és gyakorlat a magyar müemlékvédelemben (1949-1999). - Épités- Építészettudomány. 1-2. 173-203. o. 
Peschka A. (1983) Győr-Belváros „Vasudvar” tervpályázata. - Településfejlesztés. 3. 111-147. o.

Piti Z. (1987) A történeti város rehabilitációja. - A városfejlödés új útja. - Mủemlékvédelem. 2. 67-71. o.

Rácz J. (2001) A történeti városok védelmének korszerủ módja, az integrált értékvédelem. - Falu Város Régió. 2. 18-20. o.

Román A. (1973) Csapongó gondolatok a müemlékvárosok „műemléki” és városi mivoltáról. - Városépítés. 3. 24-26. 0 .

Román A. (1983) A magyar müemlékvédelem helye a világban. - Müemlékvédelem. 3. 166-176. o.

Román A. (1984a) A történeti város és városrész mint a legkomplexebb múemlék. - Müemlékvédelem. 4. 261-265. 0.

Román A. (1984b) A györi belváros tegnap és ma. - Városépítés. 3. 28-30. o.

Sedlmayrné Beck Zs. (1984) Müemléki városmagok városrendezési tervezése 1960-1980. - Magyar Müemlékvédelem 1975-79. Az Országos Múemlékvédelmi Felügyelőség Évkönyve IX. Budapest 343-373. o.

Varga Gy. (1984) Pécs telepullésfejlödése. - Városépítés. 5. 21-26. o.

Varga I. (1986) A győri történelmi negyed rekonstrukciója. - Magyar Építöipar. 9-10. 555-559. o.

Varga I. (1990) Györ történelmi negyedének rekonstrukciója. - Müemlékvédelem. 1. 15-28. o.

Varga L. (1982) Megújuló Györ. - Városépítés. 3. 28-29. o.

Winkler G. (1983) A városfelújítás tudományos kérdései. - Müemlékvédelem. 1. 1-11. o.

Winkler G. (1987) Óvárosi tömbök otthonossá tétele Győrben. - Városépités. 6. 3. o.

Winkler G. (1996) A győri tơrténeti belváros megújításának újabb szakasza. - Müemlékvédelem. 4. 234-239. o.

Winkler G. (2004) Történeti városok helyreállításának kezdetei (Györ, Sopron, Mosonmagyaróvár). Müemlékvédelem. 2.71-81. o. 